\title{
ISLAMIC APPROACH TO POVERTY ALLEVIATION
}

\author{
Dr. Abdul Ghaffar ${ }^{1}$ \\ ${ }^{1}$ Asstt. Prof. /HOD, \\ Department of Islamic Studies, \\ University of Okara, Punjab, \\ Pakistan
}

\author{
Dr. Iftikhar Alam² \\ ${ }^{2}$ Assistant Professor of Islamic Studies, \\ University of Okara, Punjab, \\ Pakistan. \\ https://orcid.org/0000-0003-2832-0324
}

Article DOI: https://doi.org/10.36713/epra6401

\begin{abstract}
It is generally agreed that poverty is a major socioeconomic problem of emerging countries; however, Islam has presented effective instruments for poverty reduction. The aim of this research is to analyze the role of instruments in poverty reduction with particular reference to Pakistan. In the process of doing that both primary and secondary data are utilized, primary data is obtained from reports etc., while secondary data is found in the text books and other publications. The study found that these instruments play a vital role in reducing poverty in the society. In Pakistan, governments have been spending huge amounts of money in form of economic empowerment, medical assistance and so forth, for example Benazir Income Support, Ushar, Zakat, Ehsas Program etc. Millions of people have benefited from such assistances. Despite this, the performance of the governments has been below expectation, due to the fact that the total money of such assistances has been below the amount required to eradicate poverty in the state. Therefore, it is necessary to see towards Islamic teachings and test the tools of Islamic Economics for eradication of today's great problem, 'poverty' which has unbalanced our society. It is needed to introduce sophisticated means of collection zakat, training of zakat personnel, mobilizing members of the public (rich) toward payment of zakat, sadaqaat, charity and other ways of assisting the poor. This article explores the key features described in above lines. Overall strategy of the study is a qualitative research based on extensive documents.
\end{abstract}

KEY WORDS:Poverty, Eradication, Welfare State, Social problem

\section{INTRODUCTION}

The word povertycomes from the old (Norman) French word poverté(Modern French: pauvreté), from

Latin paupertās from pauper (poor). ${ }^{1}$

Poverty is a state of an individual or a community in which he is deprived of even basic necessities of life. Encyclopaedia Britannica describes that poverty is a state to exist when people lack the means to satisfy their basic needs. Here needs, if narrowly defined as the needs those are necessary for the survival, or if broadly defined as the needs those are necessary for the prevailing standard of living in the community. The World Bank Organization describes poverty in this way:

1. Walter Skeat (2005). An Etymological Dictionary of the English Language. Dover Publications. ISBN 978-0-486-44052-1.
"Poverty includes low incomes and the inability to acquire the basic goods and services necessary for survival with dignity. It also encompasses low levels of health and education, poor access to clean water and sanitation, inadequate physical security, and insufficient capacity and opportunity to better one's life. ${ }^{\prime 2}$

According to United Nations Organization, fundamentally, poverty is the inability of having choices and opportunities, a violation of human dignity. It means lack of basic capacity to participate effectively in society. It means not having enough to feed and clothe a family, not having a school or clinic

\footnotetext{
${ }^{2}$. Walter Skeat (2005). An Etymological Dictionary of the English Language, New York, Dover Publications. ISBN 978-0-486-44052-1.
} 
to go to, not having the land on which to grow one's food or a job to earn one's living, not having access to credit. It means insecurity, powerlessness and exclusion of individuals, households and communities. It means susceptibility to violence, and it often implies living in marginal or fragile environments, without access to clean water or sanitation

After understanding the poverty, we describe its states existing in Pakistan, we are talking about. ${ }^{3}$

Now we see that how Islam defines poverty. We discuss it under these two headings:

1.1. Qur'anic definition
1.2. Hadithic Definition.

1.1. Qur'anic Definition: The Quran gives the objective definition. The verses denote four levels of poverty which virtually represent all such groups of individuals potentially present in any economy at any time, as is described in Al-Touba

(a) Al-Fuquara: The individuals who are living at or below the poverty level.

(b) Al-Masakin: Those living very much below it.

(c) Al-Ghari'mun: Those who are overwhelmed by debts contracted in good faith and the individuals who face natural disaster like property caught fire, agricultural epidemic, earthquake etc.

(d) Ibn al-Sabil: Those who are to live at distance from homes or who haven't enough means to meet their both hands while being on the journey and consequently face many difficulties.

1.2. The Hadithic Definition: Holy Prophet(peace and blessings of Allah be upon him) mentions that poverty or deprivation is a sort of danger and threat for both individuals and societies. It is an undesirable circumstance of which each Muslim ought to secure himself. Holy Prophet himself prayed to Allah:

"O my Allah, I refuge to you from the evils of poverty"'

$\mathrm{He}$ advised his companions to pray the following oftenly:

"Refuge to Allah from the evils of
poverty, famine, degradation,
oppressing and oppressed" 6

Consequently demonstrated that

Islam too grades destitution as an fiendish, a peril and a risk. The Prophet (peace and favors of Allah be upon him) instructed us to look for asylum from destitution. So it appears vital to set the target to urge rid of this fiendish and to create battle for it. Islam has, assist, given a few arrangements.

\footnotetext{
3. Dr, david Gordn,(2005) "Indicators of Poverty \& Hunger" (PDF). United Nations H.Q newyork, $p, 2$.

4. Al-Touba:60

5 . Ibn Hanbal, Al-Musnad, 1953

6. Ibn Hanbal, Al-Musnad, 1953
}

\section{ISLAMIC STRATEGY FOR POVERTY ALLEVIATION}

Islam is a universal religion. It presents everlasting solutions of all social problems. We can find clear guidelines from teachings of Islam to alleviate or reduce poverty. Here are some points little more important.

Each Muslim, anything his financial position is to work to fulfill his part in accomplishing feasible improvement agreeing to his intrinsic conceivable outcomes and his procured abilities.

Earning and obtaining properties is a fundamental job for each Muslim. Hence, earning to make assets and keep up great standard of life may be a important exertion and adore. Allah says in Holy Quran:

for."

"Man can have nothing but what he strives

The

Prophet guarantees the significance and sacredness of working. ${ }^{8}$

\subsection{Zakat}

A vital approach degree for destitution annihil ation in Islam is Zakat. It may be a required obligation for the well off individuals to pay Zakat. It is a very important source for destitution easing on the off chance that work isn't accessible or its return isn't adequate to fulfil the necessities of life. Each and every affluent Muslim should perform Zakat to total his adore to Allah. ${ }^{9}$

Every person who has 52.5 tolas of silver or 7.5 tolas of gold or its value in addition to essentials, houses and riding, etc., should spend $2.5 \%$ of his annual income in the way of Allah. That is, if a person has one lakh rupees, he should spend two and a half thousand rupees in the way of Allah and spend it on the poor and needy. Details of who can be given the amount of Zakat and who are entitled to it are available in the books of jurisprudence. There are two main benefits to the Zakat system.

1. Commodity is in circulation. In other words, if a person has a crore, he is obliged to pay Zakat of two and a half lakh rupees. Similarly, as the value increases, the proportion of the amount of Zakat will also increase. Stays in circulation

2. It helps other poor and needy people. By helping them financially, they are prevented from reaching out to anyone.

\subsection{Ushr}

It is calculated as five percent of agricultural production of the land depending on manual irrigation and ten percent of agricultural production of the land depending on natural irrigation.

\footnotetext{
7. Fatir:39

${ }^{8}$. Bukhari, Al-Jame Al-Sahih, 1976

9. Al-Ma'un:1-7
} 
And for the cattle not being used for farming or the activities like that. Ushr is necessary to be paid, mostly in-kind, while harvesting time. ${ }^{10}$

\subsection{Sadaqat}

This term is utilized within the Qur'an to indicate all social consumption or investing counting the obligatory one, Zakat. Its base is "sadaqa" which suggests speaking the truth and bein true. Sadaqah is a free-will offering given for the sake of Allah by a Muslim out of worship, sensitivity and sympathy for others, also what he is morally or legally obliged to give without foreseeing any common return. Sadaqah is, consequently, social and charitable blessings or favors. ${ }^{11}$

Sadaqat play a basic part within the Muslim community. Indeed where needs may have been fulfilled and destitution expelled, they give ceaseless private assets for assembly individual and open needs, and advancing social improvement.

\subsection{Auqaf}

Giving away a kind of social benefit to service to a Muslim, not having resources or riches for the purpose of Allah, in favor of a category of individuals until the end of time. Auqaf, as a rule, give merchandise and administrations that offer assistance profoundly in destitution easing and social improvement through assembly instructive, social, social, wellbeing, foundation and common betterment reasons. These are used for covering social necessaties (merchandise and administrations), giving an affluent, exceedingly created community, all through a long period welfare of an Islamic society. Holy Apostle(peace and blessings of Allah be upon him) energized this type of riches commitment back social improvement. It is one of the deeds of a Muslim that continues to gather rewards even after his death. Sadaqat can play a critical part by giving essential stores to Auqaf, charitable trusts and establishments.

\subsection{Tauzif}

Another discretionary obligation,

in Islam, for poverty alleviation, is Tauzif. It is a discontinuous commitment as compared to Sadaqat and Auqaf. It is associated because it were in certain occasions. It is comparative to common charges, but to be collected because it were from the wealthiest inside the society

to come over unprecedented budgetary, social or/and political issues and for an obliged period of time. It is the obligation of the government to choose the clear causes to accumulate them, the level of wealth that must take portion in these installments, the time

\footnotetext{
10. Al Qaradawi, 1981

11. Al-Baqarah:263-4, 271, 276
}

required to overcome issues they are suggested to comprehend.

So too, when a require of work openings wins, Islam slants for course of action of capital through grants and propels to enable the unemployed/underemployed to conclusion up palatable income-earning people of the society. Meanwhile, Islam fights for an ampleness wage-structure and equalization of work and educator openings course of action that lead to extended compensation potential and openings. ${ }^{12}$ These Islamic apparatuses focusing on destitution easing have profound positive impacts on social elevating. Satisfying the obligatory and discretionary obligations (Zakah, Sadaqat and Auqaf) as a commitment to the Muslim give a copious sum of return collected annually. The multiplier impact of these assets will be through their effect on expanding utilization, yield, business and pay within the society.

\subsection{Charity}

In addition to making Zakat obligatory, Islam emphasizes that every Muslim should give some of his income to the poor and needy, meet their needs, help them in need, and give clothes to those who do not have clothes. If they do not have food, the best way to feed them and help them is to get them on their feet or to teach them in a short period of time so that they can be employed or at least not given enough money to run their business on a small scale.

The work of making the poor out of the country or giving them money for employment can also be done through Zakat but only the deserving ones have to be included in it. While through charity everyone can be helped in general regardless of their status. The biggest way is that people who are unemployed but educated and have the passion to do something, so people who have the capital but don't have the time or experience to do business, by making these educated unemployed people share in the profits and can solve a big problem of the society.

In Islam, this is known as mazaarbat, meaning hard work on one side and capital on the other. If done with honesty and integrity, it is not far off that it will not only solve the problem of poverty but also Muslims will raise the banner of their success in the field of trade. The condition is that both parties should be honest and not think of exploiting their partner's capital or hard work.

\subsection{Some Other Important Measures}

Firstly, it is well known that poverty leads to crimes and corruption. Many nations suffer from it and are looking for solutions to this problem and

\footnotetext{
${ }^{12}$. Mehboob-ul-Haq,Reflections on Human Development, Oxford University Press. 1st edition 1996, p. 199

ISBN 0-19-510193-6.
} 
there is no solution except in Islam, which brought rulings for all people until the Day of Judgment.

Secondly, the means that have been prescribed by Islam to solve the problem of poverty and combat it are as follows:

\section{(a) Teaching Patience}

By teaching people to believe truly that provision comes from Allah and that $\mathrm{He}$ is the Provider (alRazzaaq), and every calamity that Allah decrees is for a reason, and that the poor Muslim should be patient in bearing his calamity and strive to relieve himself and his family of poverty is very key. Allah says:

"Verily, Allaah is the All-Provider, Owner of Power, the Most Strong. '13

\section{(b) Encouragement to Help the Needy} and Support the Weak

Nou'man ibn Basheer said that Prophet (SAW) said:

"The likeness of the believers in their mutual love, mercy and compassion is that of the body; when one part of it is in pain, the rest of the body joins it in restlessness and fever."14

\section{(c) Helping each other}

Economy is related to every aspect of human life, individual and collective, and since the congregation is the body and the individual is a part of that body. Therefore, there is an inseparable relationship between the collective and individual spheres of life and it is inevitable that one will affect the other.

\section{(d) Incentives for the earning in the welfare state}

The first destination in economics is the destination of "economy" and "provision of sustenance". The Holy Qur'an says that every human being must strive for the economy to the best of his ability. The world is a field of action. Stagnation here is tantamount to death. In this workshop, God Almighty has amassed a wealth of sustenance, but it is a condition to seek sustenance. It is instructed in the Holy Qur'an:

\section{"And how many other people are wandering in the land, seeking the bounty of Allah Almighty."15}

Hazrat Umar Farooq (may Allah be pleased with him) said:

"None of you should sit down in the struggle for sustenance."16

Moreover man is encouraged to struggle and move for earning a living and it is said that man should earn his own living with his own hands. ${ }^{17}$

\footnotetext{
13. Al-Dhaariyaat 51,58. See also, Q11v6, Q67v21, Q17v70.

14. Bukhaari, Al-Jame Al-Sahih, Hadith: 5665

15. Al muzammil:20

${ }^{16}$. Ibn-e-Aseer, Usdul Ghaba, p.4202

17. Ahmad bin Hanbal, Al-Musnad, 502/28
}

\section{(e) Teachings of Holy Prophet:}

Human history bears witness to the fact that economic and social justice and stability in human society is not possible without the holistic and allencompassing implementation of the religion (system of life) of God's choice, which He has chosen. Through the Holy Prophets (peace and blessings of Allah be upon him), the holy people have bestowed blessings on humanity for the worldly and otherworldly welfare, and the fulfilment of which was accomplished through its last Prophet, Hazrat Muhammad (peace and blessings of Allah be upon him). We firmly believe that man will continue to suffer in the world as long as he does not bow down to the teachings of Prophet Muhammad. He will never be able to achieve peace and harmony, economic prosperity and social justice in life.

Sirah-e-Taiba for the eradication of basic and vile human evils in the world such as oppression and injustice, hunger, poverty and misery, self-imposed exploitation and unjust law, unnatural economic and social inequality and imbalance and attainment of worldly and otherworldly happiness. It is necessary to follow the teachings and instructions of the Prophet (peace and blessings of Allah be upon him).

\section{(f) Encouragement for working hard}

We are well aware that one of the most important primary and key means of generating wealth is the personal labour of human beings, without which many divine treasures cannot be profitable in the raw state. One of the reasons for poverty, misery and decline in income and productivity in our society is to live off this source of wealth (labour). Allah says:

"He it is Who made the earth subservient to you, so follow in its footsteps, and eat of what is given to it, and to Him is the resurrection." 18

When we study the biography of the Prophet (peace and blessings of Allah be upon him) in terms of hard work, we see that the honour and dignity which he gave to hard work and labour to an encouraging and enviable extent. Existence did not exist on earth before the advent of the Prophet (peace and blessings of Allah be upon him) nor is it found in today's civilized and well-meaning human rights world. The Prophet (peace and blessings of Allah be upon him) encouraged people to eat by hand. He said:

"There is no better food than eating by hand and (that is why) the Prophet of God, David (peace be upon him) used to eat by hand (despite being a king)."19

On another occasion, he said:

"It is better for one of you to carry a bundle of wood on his back, that is, to

\footnotetext{
${ }^{18}$. Al-Mulk: 15

19. Bukhari, Al-Jame Al-Sahih, Hadith:1205
} 
earn money by selling wood, than to raise hand in front of people and then give it to someone or not." 20

What could be more encouraging and respectful than the fact that the Prophet (peace and blessings of Allah be upon him) kissed the hands of a labourer Companion with his blessed lips and said:

"These are the palms that Allah loves."21

It is narrated that the Prophet (peace be upon him) said about a labourer hand:

"This is the hand that will not be touched by fire."22

The book revealed to the Holy Prophet (peace and blessings of Allah be upon him) also encourages us to migrate to another place in the vast land of Allah if there are no suitable and reasonable opportunities for employment in spite of hard work. We will give prosperity and breadth. He said:

"And whoever leaves his home in the way of Allah, he will find in the earth many places (for emigration) and prosperity." 23

\section{(g) Indoctrination of Self-Sacrifice and Spending}

In any welfare state, it is natural for people to find economic disparities, that is, for some to be rich and wealthy, for some to be in need, and for some to be poor and needy. Man is obliged to follow the system of creation given by the last Prophet(peace and blessings of Allah be upon him) instead of the system of creation. Thus, Muhammadan Shari'ah does not believe in unnatural equality in the degrees of economy like socialism, but it has equated all human beings without any distinction in the "right to economy". To this end, he has used the teachings of benevolent, voluntary and fraternal compassion, i.e mutual sympathy and compassion.

Therefore, the problem of poverty is mostly solved by these unique and effective teachings of Muhammadan Shari'ah. The rest of the deficit is removed with the help of law.

When some people of the tribe of 'Madhar' came to the service of the Prophet (peace and blessings of Allah be upon him) barefoot and dressed in torn old clothes, seeing their dilapidated condition, the face of the Prophet (peace and blessings of Allah be upon him) changed. The Prophet (peace and blessings of Allah be upon him) did not feel at ease until the signs of happiness appeared on his face until he had the necessary equipment for their distress. ${ }^{24}$

These were the beautiful teachings of the Holy Prophet(peace and blessings of Allah be upon him)

\footnotetext{
${ }^{20}$. Bukhari, Al-Jame Al-Sahih, Hadith:1042

${ }^{21}$. Tibrani, Suleman bin Ahmad, Al-Moujam Al-

Ousat, Hadith:8934

${ }^{22}$. Ibn-e-Aseer, Usdul Ghaba:4202

23. Al-Nisa: 100

${ }^{24}$. Muslim, Al-Jame Al-Sahih, Hadith:3271
}

which on the one hand created in the hearts of the nobles and the rich the feelings of love for the poor, compassion, benevolence, sorrow, self-sacrifice and brotherhood.

\section{(h) Promoting Simplicity instead of Luxury}

One of the major causes of poverty in a welfare state is the indulgence of its rulers, especially those in power, in extravagant extravagances. As per Islamic point of view, no man, not even the head of state, can discriminate against the common man in terms of living, eating and other human rights. The division between VIP and non-VIP is un-Islamic. Who could be a VIP in the world more than the Prophet(peace and blessings of Allah be upon him)? In spite of this, often meal was not prepared for the days, even no pair of clothes had ever been folded for him.

The room of no spouse of Prophet of Allah, was made of any kind of marble, teak wood or "imported" materials. The details can still be found today. The Prophet (peace and blessings of Allah be upon him) said:

" A void luxuries because the servants of God do not indulge in luxuries." 25

*In times of general poverty, the Prophet (peace and blessings of Allah be upon him) did not like the upper room of a Companion's house. ${ }^{26}$

*When he saw the curtain on the door of the house of Syeda Fatima Al-Zahra, he did not like to enter the house. ${ }^{27}$

So, these statements show that we find the examples of simplicity and contentment instead of luxurious life, in seerah of the Prophet (peace and blessings of Allah be upon him).

\section{(i) Eradication of Bribery and Corruption}

Bribery after usury is rampant in our society which has engulfed the whole society. Bribery is what it is; right should be given to falsehood and falsehood to right. Ibn 'Abidin says:

"Bribe is something that a person gives to a ruler or a non-ruler for the purpose that the decision is in his favour or he is promoted to the position of his choice. ${ }^{28}$

The Prophet (peace and blessings of Allah be upon him) has made very painful warnings against bribery and those who take and give it. Abdullah ibn Umar (may Allah be pleased with them) narrates:

\footnotetext{
${ }^{25}$. Tabrezi, Muhammad bin Abdullah, Mishkat AlMasabih,449/3

26. Abu Dawood, Suleman bin Ashath, Al-Sunan, Hadith:1711

27 . do, Hadith:572

${ }^{28}$. Ibn Abidin, Radd-ul-Muhtar Ala Al-Durr AlMukhtar, 453/1
} 


\section{"The Prophet (peace and blessings of Allah be upon him) cursed the bribe-taker and the bribe-giver." 29}

Man's nature has been created in such a way that he is obsessed with materialism, the desire to achieve the maximum of it in the world, always exists in his heart. This human weakness is mentioned in many places in the Qur'an. Allah says:

"He is deeply in love with wealth." 30

On another place, Allah says:

"And you consume all the wealth

of the inheritance and eat it, and

cherish the wealth with all your heart." 31

That is why man does not have patience in what he gets in a lawful way, but adopts every unlawful way to gain more, even though if he thinks about it, Allah has made it very clear that the more wealth a person acquires from lawful sources, the better for him if he is patient with it. ${ }^{32}$

\section{(j) Discouraging Usury}

The literal meaning of usury is to be more, to grow, and to go higher. This word appears in the Holy Qur'an in several verses. Imam Ragheb (may Allah have mercy on him) writes:

"The excess of capital is usury.

But in the Shari'ah, it is specific to

an excess that is in one particular way and not in another." 33

Abu Hayyan Gharnati defines 'usury' as:

The practice of taking interest on a loan by lending it to someone and increasing the interest on it for as long as the loan lasts is called usury. The Prophet (peace and blessings of Allah be upon him) defines usury as:

"The loan that makes a profit is usury." 34

However, the Prophet (peace and blessings of Allah be upon him) also included some forms of sale and purchase in the concept of usury, which the Arabs did not consider usury. For example, in the sale and purchase of six things, it was ordered that if they are exchanged, they should be equal and the cash should be in hand. Barley, dates and grapes.

Following the same principle, the Prophet (peace and blessings of Allah be upon him) forbade

29. Ibn Maaja, Muhammad bin Yazeed, $A l$ -

Sunan,Hadith;2313

${ }^{30}$. Al-Aadiyaat:08

31. Al-Fajr:19-20

32. Hood:86

33. Raghib Asfihani, Hussain bin Muhammad, Tafseer

Al-Raghib Asfihani, 245/1

34 . Al-Mawardi, Al-Hawi, 356/5 some of the forms of affairs in Arabia which were common in the name of mazabna and mahaqila. ${ }^{35}$

There are so many teachings of Shariah condemning usury. Islam has encouraged business instead of usury. The reason behind it is that it is so obvious that real profit lies in business. So if usury system is eliminated from a society, positive results may be got in form of alleviation or lessening of poverty.

\section{POVERTY ALLEVIATION MODEL}

In the time of Umar bin Abdul Aziz, people were given so much stipend that by doing business they would join the ranks of Zakat payers the following year. Within a year, the people became so prosperous that there was no one to receive charity. For this, besides taking the above discussed measures, he additionally took the following steps.

\subsection{Reduction in Expenses}

He substantially reduced the expenses of the Caliphate and all its adjoining offices. He issued orders to the princes and rulers of all the states to adopt simplicity and austerity. Abu Bakr ibn Hazm, the governor of Medina, asked for an increase in the cost of pen and ink, and he wrote back:

"Sharpen the pen, write the lines closer together. Use frugality in other needs. You will not get a single dirham from the treasury of the Muslims in this regard." 36

Sayyidna Umar's son says:

"When the father became caliph, the annual income was forty thousand dinars, but when he died, the annual income was less than four hundred dinars." 37

\subsection{Return of Property to the Real Owners}

Two-thirds of the wealth of the Muslim Ummah held by the Umayyads was returned to the treasury. All confiscated property and estates were returned to their original owners. It is narrated on the authority of Salman ibn Musa:

"I saw that Umar bin Abdul Aziz, from the day he was made the caliph until his death, continued to restore the rights of the people." 38

\subsection{The Right of the Poor to the Treasury}

\footnotetext{
${ }^{35}$. Hakim Neshapuri, Muhammad bin Abdullah, AlMustadrak Ala Sahihain, 327/1

${ }^{36}$. Ibn Jouzi 1984, Sirat Omer bin Abdul Aziz, Beirut: Dar Al-Kutub Al_Ilmia, p.108

${ }^{37}$. Ibn Kathir, Ismail bin Umar, Al-Bidayah wa AlNihayah, Karachi: Nafees Academy, p.188

${ }^{38}$. Suyuti, Abd-ur-Rahman bin Abu Bakr, History of

Caliphs, Kolkata: Oriental Press,1970, p. 123
} 
He got prepared lists of orphans, widows, the poor, the disabled, the unemployed and infants, and fixed their stipends from the state treasury. ${ }^{39}$ The doors of the treasury were opened for the needy.

\subsection{Multiple Increase in the Treasury Income}

By waiving of the jizya of new Muslims and issuing benefits, the income of the treasury decreased. He made the strictest arrangements for the protection and supervision of the treasury. He made the collection and distribution system transparent. In this regard, such the strictest laws were enacted that after the equitable distribution of wealth and the elimination of illicit income, the revenue of the treasury multiplied in a single year.

\section{CONCLUSION}

After having somewhat a brief discussion, we consequently reach to conclude that Islam is the only religion who presents several solution to a single social problem, as we discussed here in this article. So, the requirement is that these guidelines should be followed by the individuals of a Muslim state. As others have took guidance to establish their economics, Muslims should also align their economy in the sparkling light of everlasting Islamic system of economics. It is the only way to alleviate or, at least decrease the poverty. So, we recommend here for the states that legislation should be conducted in light Islamic economic system, if laws already exist, so theses should be enforced. Besides this, individuals should also follow the points given here, to balance their economic position.

${ }^{39}$. Ibn Jouzi 1984, Sirat Omer bin Abdul Aziz, p.112 